\title{
Enacting Alternatives to Nationalist Essentialising in Language Learning: Students' Voices
}

\author{
Gloria De Vincenti ${ }^{\mathrm{a}}$ and Angela Giovanangeli ${ }^{\mathrm{b} *}$ \\ ${ }^{\mathrm{a}}$ Independent Scholar; ${ }^{\mathrm{b}}$ University of Technology Sydney
}

*Angela.Giovanangeli@uts.edu.au

Gloria De Vincenti has worked as a lecturer in the School of International Studies of the Faculty of Arts and Social Sciences at the University of Technology Sydney, where she taught Italian language and culture. Her research interests include intercultural education, language and identity and Italian Futurism.

Angela Giovanangeli is a senior lecturer in the School of International Studies of the Faculty of Arts and Social Sciences at the University of Technology Sydney where she teaches courses in French studies. Her research interests include intercultural education, language education and cultural practices 


\title{
Enacting Alternatives to Nationalist Essentialising in Language Learning: Students' Voices
}

\begin{abstract}
Researchers examining nationalistic conceptions of language learning argue that nationalist essentialism often shapes the way languages are taught by educators and understood by learners. While numerous studies focus on how frameworks informed by Critical Discourse Analysis (CDA) and intercultural education offer alternative approaches to national stereotyping, these studies tend to focus on theoretical approaches, teacher perspectives or innovative teaching and learning resources. The literature to date, however, does not provide case studies on student responses to activities designed by the teacher to open up the classroom with opportunities that move beyond essentialist representations. This paper responds to the need for such scholarship and presents a case study involving a focus group with tertiary students in an Italian language and culture subject. It reveals some of the ways in which students enacted and reflected upon alternatives to nationalist essentialising as a result of language learning activities that had been informed by the discursive processes of CDA. The findings suggest that students demonstrated skills and attitudes such as curiosity, subjectivities and connections with broader social contexts. Some of the data also indicates student engagement in critical inquiry and their potential for social agency.
\end{abstract}

Keywords: nationalist essentialising, Critical Discourse Analysis, language learning, student perspectives, intercultural, subjectivities

\section{Introduction}

The critique of foreign language classrooms as sites of nationalist reproduction is not new. Literature on the impact of nationalist essentialising in language learning suggests that nationalist discourses present homogenous and static representations of target cultures that fail to reflect diversity and complexity (Starkey, 2007; Dervin and Liddicoat, 2013; De Vincenti, 2017). Scholars such as Adrian Holliday have for a long time maintained that 'the common image of cultures as national structures that define and confine us is an 
illusion forged by Western ideology both in the academy and in society more generally' (2011a, 44).

In recent studies, certain researchers have been advocating for a Critical Discourse Analysis (CDA) approach in language learning to help identify discursive processes commonly associated with essentialist productions in language (Cole and Meadows, 2013). According to such studies, discursive processes such as objectification, prescription and alignment, embedded in language materials and classroom practice, can confine language learning to the representations of nationalist essentialism. These same studies argue that raising awareness of such processes can allow language teachers to develop strategies which move away from nationalist representations to engage rather with diversity embedded in social realities (35).

While research on nationalist essentialising in language teaching is plentiful (Risager, 2007; Starkey, 2007; Holliday, 2011b; Morgan, Kohler and Harbon, 2011; Cole and Meadows, 2013; Dervin and Liddicoat 2013; Weninger and Kiss 2015; De Vincenti, 2017) these studies tend to focus on theoretical frameworks such as CDA, teacher perspectives or teaching and learning resources such as language textbooks. Literature on student responses to activities, designed for their potential to open up the classroom with discussions challenging essentialist representations, is scarce. In order to address this gap in the literature, this paper responds to the need for such scholarship through a case study involving a focus group of tertiary students in an Italian language and culture subject. The aim of this work is to identify how students involved in the case study enacted and reflected on cultural representations generated by a language activity that had been shaped by the teacher's awareness of the discursive processes of CDA.

The focus of this study is divided in three sections. Firstly, we begin by reviewing nationalist essentialising in language learning and why this is problematic to the current 
intercultural approach of language education. Then we present a brief overview of how an understanding of CDA provides language teachers with the potential to set up activities that move away from essentialised notions of languages and cultures. Finally, we present the case study and turn to data from an Italian language classroom focus group to examine how students respond to the language activity that had been designed to tackle nationalist essentialism. Additionally, we will reflect on the relevance of the student responses to intercultural education.

\section{Nationalist Essentialism and Intercultural Education}

Scholarly work on foreign language learning from the 1970s to the present day holds the view that nationalist essentialism shapes the way languages are taught by educators and understood by learners (Bourdieu and Passeron, 1977; Golden, 2001; Starkey, 2007; Meadows, 2009; Holliday, 2011b; Morgan, Kohler and Harbon, 2011; Cole and Meadows, 2013; Dervin and Liddicoat, 2013; Risager and Dervin, 2014; Weninger and Kiss, 2013). According to language scholars Cole and Meadows, nationalist essentialism takes place in language classrooms in two distinct ways: firstly, by programs that idealise individuals as monocultural; and secondly, by limiting language to a standard practice thereby diminishing the visibility of linguistic diversity and practices (32). These authors highlight the paradox that exists for educators by arguing that on the one hand language teachers are 'aware of the dangers of essentialism' but on the other continue to 'teach and write and think as though discrete categories of culture and language exist' therefore contributing to the stereotyping of certain national constructs. $(2013,30)$. This discussion is particularly relevant in light of contemporary language education discourses that are increasingly underpinned by an intercultural approach. According to Abdallah-Pretceille, the term 'diversity' should be one of the key features of intercultural analysis. For her, a 
'perspective of diversity' highlights 'intra-group and inter-individual differences' rather than 'inter-group differences' (Abdallah-Pretceille, 2006, 476). Here Abdallah-Pretceille highlights the meaning of diversity not only across specific groups but within groups themselves.

This view of diversity based on intra-group and inter-individual differences resonates with Liddicoat and Scarino's (2013) view on the intercultural understood as a process that encourages 'personal engagement with diversity', and 'interpersonal exchanges of meaning' (8) that 'decenter learners form their pre-existing assumptions and practices' (29). Consequently, the intercultural approach is critical of essentialist views because it views languages and cultures as dynamic and positions the learner at the centre of learning. Similarly, Michael Byram's work on intercultural education refers to the 'demotic discourse about culture' referring to how culture is 'multifaceted and diverse in its range of values, beliefs, practices and traditions' (Byram, 2009a, 5). In this work, Byram highlights how cultures are 'continually being redefined by individuals and groups as they interact with others of different background or respond to changing circumstances’' (Byram et al., 2009c, 3).

Within this context, language textbooks and resources have always been seen as pivotal in how language learners develop language skills (Weninger and Kiss, 2013, 695). However, research on language textbook analysis suggests that teaching materials contribute to the essentialist narratives shaping language classrooms because they often fail to represent real world contexts such as cultural diversity, flexibility and complexity in the language program that Abdallah-Pretceille, Liddicoat, Scarino and Byram refer to above (see also Kramsch, 1998; Risager, 2007). This research argues that the difficulty of language textbooks lies in the fact that resources can limit understandings 
of culture. For instance, one of the authors of a paper exploring the design of language textbooks reflects that:

\footnotetext{
It is now appearing to me clearer than ever, that the task of writing a textbook with an intercultural orientation is a real problem in itself, that is, the genre of textbook means you have a finite corpus, but the notion of intercultural means you should keep digging and noticing and asking and languaging and exploring culture forever and ever, indicating really that the corpus is infinite (Morgan, Kohler and Harbon, 2011, 44).
}

This notion of the 'infinite' corpus relates to the constantly shifting and evolving nature of culture.

\section{The utility of Critical Discourse Analysis in raising awareness}

While nationalist essentialising poses challenges to intercultural education by disengaging with cultural and linguistic diversities, there are language scholars who view CDA as the 'ideal tool' to help make teachers and students aware of 'alternative versions' of cultural practices at the centre of intercultural encounters (Cole and Meadows, 2013, 33). Indeed, CDA represents a useful tool to understand the ideological components of texts and to investigate the role of texts in the perpetuation or challenge of ideologies (Blommaert and Bulcaen, 2000; van Dijk, 2001; Paltridge, 2006; Cole and Meadows, 2013). In the area of language learning, research suggests that CDA allows us to identify the ways in which teacher discourse can function to essentialise language and culture (Cole and Meadows, 2013, 35). Cole and Meadows specifically adopt a CDA framework in their work to make visible three discursive processes in language classrooms: 
objectification; prescription; and alignment, to reveal how essentialist discourse and practices are constructed in language classes $(2013,35)$.

With regard to the idea of objectification, Meadow and Cole refer to the ways in which conventional language classrooms use discourse to appropriate ways of speaking, listening and writing that is tied to nationalist type (36). Through objectification teachers may limit student attention to specific language formations that do not include variations within the language according to relational frames such as geographic variations of language.

As for the term prescription, this is defined as 'the explicit direction from a position of authority to shape linguistic and cultural practice' (37). This refers, for example, to the way nationalist essentialising might be enacted through textbook and/or teacher's instructions in relation to pair or group activities (see De Vincenti, 2017, 8).

The final term alignment relates to how culture and society may be reinforced by the way individuals such as teachers may 'align' themselves with the nationalist agenda. These authors refer to the 'monoglossic effects' teachers can have on 'heteroglossic realities' and note how language teachers, for instance, 'shuttle between first-person singular and plural pronouns $(\mathrm{I}>\mathrm{we})$ in order to position themselves within a mainstream, nationalist center', hence objectifying cultural practices and aligning 'the individual self with the nationalist collective' (Cole and Meadows, 2013, 38).

According to Cole and Meadows, these same discursive processes of objectification, prescription and alignment' that promote nationalist essentialism can also be redirected to denaturalise nationalist essentialising and 'make voices from the Periphery audible in classroom discourse' (39). This can be done by recognising how these processes are performed and subsequently deconstructed to bring to the surface and to legitimise cultural plurality in foreign language learning. 


\section{Context of study}

Drawing on how the discursive processes of objectification, prescription and alignment can be redirected away from essentialism in language learning, this study uses as a starting point a language activity designed and implemented in a university language and culture class. The design of this activity was informed by a shift away from the teacher's alignment with textbook activities and teacher discourse that objectified language and culture to an activity designed to encourage exploration of cultural plurality.

The activity in question related to a unit on food and eating habits and was implemented in the curriculum of an Italian foreign language course at beginners' level, in a large urban Australian university. It involved two cohorts and the class composition included a total of 45 students enrolled in various degrees across the University: combined degrees (Bachelor of Arts in International Studies combined with a professional degree); Diploma in Languages; sub-majors in Italian language and culture or electives. More than $50 \%$ of the students were enrolled in combined degrees, involving one academic year of exchange study in the fourth year of their program, at a partner university in Italy. The subject was delivered over twelve weeks: two sessions of two hours per week. It focused on developing language skills to communicate in oral and written form, as well as exposing students to the cultures and societies of multicultural Italy through an intercultural approach. While the subject was supported by the language textbook New Italian Espresso and additional resources, the design of the activity acknowledged the previously mentioned limitations of language textbooks and the significance of designing activities that move away from the national imaginary in order to achieve student engagement with Abdallah-Pretceille's notion of a diversity of perspectives (see also De Vincenti 2017). 
The language activity was titled 'Dove vai a mangiare a Milano?' [Where do you go to eat in Milan]. It invited students to visit an Italian website that presented a broad range of budget eateries and cafés in Milan. The website on which the activity was based listed 85 eateries, 32 of which were Italian and included regional cuisine, pizzerie, street food, paninoteche, piadinerie, rosticcerie and librosterie (bookshop and cafe). Other types of cuisine were also represented: 5 Japanese restaurants, 6 Chinese (including two Chinese restaurants with an Italian influence), 3 Turkish, 3 Sri Lankan, 4 Indian, 2 Filipino, 1 Vietnamese, 1 Korean, 1 Egyptian-Italian, 1 Ethiopian, 1 Greek, 1 Uzbekistani-RussianKorean, 4 vegan. There were also 9 gelaterie/pasticcerie, 4 bars and 7 other places serving drinks and snacks, the main attraction being indoor or outdoor activities.

In this activity the following questions were designed inviting students to explore and engage in the Italian language with information drawn from the website:

1) List five different types of cuisines available in Milan,

2) Select one eatery for an outing in Milan and explain why,

3) State why you chose to eat at this particular eatery,

4) Explain how much one meal cost on average,

5) Describe where this eatery is located.

The first question was designed with the intention of bringing diversity to the forefront with regard to the food practices in Milan. The remaining questions were shaped to foster engagement with diversity. Bringing diversity to the forefront opened up the classroom to the fact that Italy is a multicultural country. As much as this fact is fundamental, it is the interaction that spins the multicultural fact into a process of exploration and reflection. Students were prompted to act, make choices by visiting the restaurant websites and seeking additional information on atmosphere, menu, cost and location. Many eateries 
provided information on the business owners and concepts behind their restaurants. The activity was designed for a beginner language level and asked the students to use the present tense. The activity designed around giving students choices was also conducive to a dynamic approach by positioning the student at the centre of the task. Reflection was embedded in question two asking students where they go and why. While aware that students had limited language resources to expand on their choices, the question had the potential to trigger a deeper level of involvement that included connections with personal and subjective viewpoints.

In light of Cole and Meadows' work on CDA, the teacher framed the activity to shift away from essentialist conceptions in teaching and learning resources. The use of the website was intentional in order to move away from static representations of food in language textbooks and to capture the dynamic representations of food practices in a contemporary city. The classroom was positioned into a space open to alternative voices, hence moving away from the risk of alignment and prescription processes referred to in Cole and Meadows' (2013) work. None of the eating options in Milan included on the website were ruled out, unlike a tendency of the activities in the prescribed language textbook that focused specifically on traditional national Italian cuisine. The table below reveals the types of eateries selected by the forty five students involved in the activity.

Table 1. Restaurants chosen by students in activity 'Dove vai a mangiare a Milano?'

This was followed by a focus group session at the end of the semester led by the authors of this study, of which one was their teacher during the semester. The aim of the focus group was to obtain input from the students based around how they responded to the language activity on food. 
Focus groups were formed based on students' availability to attend one of the five proposed 50-minute sessions on different days of the same week, at the end of the course. Students were invited to participate by email and three face-to-face groups were formed, with a total of 9 participants. As Table 2. below shows, the students (pseudonyms used) come from a variety of backgrounds, including a Romanian exchange student from the UK. The Italian/Australian students were familiar with Italian dialects: calabrese, siciliano and veneto, Most participants had also travelled overseas and spoke other languages such as French, Spanish, Portuguese and Japanese. They also came from a variety of disciplinary backgrounds, including international relations and politics, architecture, industrial design, journalism, science, engineering.

Table 2. Profile of Student Participants

The five questions below were distributed to students by email a few days prior to the focus group session and then discussed during the face-to-face meeting These questions addressed students' reflections and expectations on their learning experience.

1. What do you expect from a language and culture subject in terms of fostering knowledge of culture and society?

2. As you reflect on what was covered in your classes, is there any aspect you didn't expect about lifestyle in Italy?

3. What did you think of the socio-cultural task 1 'Dove vai a mangiare a Milano?'

4. What do you expect from an Italian as a foreign language textbook in terms of representations of culture and society? 


\section{Data analysis}

\section{Diversity of perspectives}

This section draws on data from both the activity and the focus group in order to examine student responses. In the task 'Dove vai a mangiare a Milano?', responses to the first question indicated in Table 1. above asking students to list 5 different types of cuisine, 24 students selected Italian cuisine which also included Italian street food, and regional cuisine, hence expanding considerably the range of Italian cuisine they were familiar with, prior to the task, and exposed to through their textbook. The remaining students which constituted almost half the group, selected a variety of eateries, the most popular being Japanese and Chinese, including Chinese with an Italian influence.

This task set the basis for an inclusive understanding of food related discourse. In the following weeks and throughout the course, whenever the conversation involved questions about food options, the question was addressed by drawing on the vocabulary learned through the activity. In these classes there was a noticeable shift in classroom discourse, compared with cohorts in previous years, where conversation on food often revolved around traditional and popular Italian cuisine. Meanwhile, the activity promoted the development of vocabulary that reached beyond nationalist ideologies.

Discussion in the focus group revealed that the activity triggered enquiry into diverse food contexts. For instance, one of the students Sonia in the focus group confirmed that this activity prompted her to search adjectives to express cuisines that extended to broader contexts beyond that offered in the Italian language textbook. She noted that when she came to listing her five restaurant options she had to 'word reference Middle Eastern restaurant' because she had not previously been exposed to this vocabulary in Italian before the activity. Similarly, Vera in the focus group responded to this comment by adding that 'this is something they wouldn't teach us in the textbook'. 
Indeed, while introducing a list of adjectives of nationalities, the prescribed textbook was predominantly Eurocentric. By including the term Middle Eastern in her list of five cuisines in Milan, the student made visible terms that were connected to the realities of cultural practices in Milan. Consequently, the design of a language task that foregrounded a 'perspective of diversity' (Abdullah-Pretceille, 2006, 478) gave agency to social realities through language production, which subsequently impacted classroom discussion. This interplay between language production and discourse corresponds with Young and Harrison's point on how language is 'dialectical', meaning that language influences discourse and this in turn influences the language that is used. $(2005,369)$.

\section{Challenging stereotypes}

Focus group responses revealed multiple aspects relative to students' discoveries in the process of engaging with diversity. These responses unveiled a realisation of preconceived ideas towards practices of the target culture. The notion of surprise was a recurring theme in the focus group discussion with regard to what students discovered about eating options in Milan. For instance: Gavin stated 'I was surprised by the variety of different types of restaurants' further noting that he knew Milan was a multicultural city, but 'didn't expect that many Japanese restaurants, I thought that was unique for Italy'. Similarly, Matthew related that 'I wouldn't have thought that there would be a lot of Asian in these sorts of European countries'. Likewise, Sonia noted with regard to what she learnt from the activity 'I didn't realize how diverse the country was'. Andrew highlighted that the tasks gave him a 'better insight into what actually Italy is now' adding that this process of discovery 'is to break down all the ideas I had' in relation to what to expect in cuisine available in Italy'. For Vera, the task allowed her to rethink the stereotypical association of cuisine in Italy being solely Italian. In the focus group she 
reflected that 'I don't imagine going to Rome and then going out for sushi, this is something that you don't really think about. It wasn't something I had thought about at all until I did that assessment.' Indeed, some of the students in the activity selected restaurants based on their curiosity to explore what they refer to as 'interesting' or 'new experiences'. For instance, Bobby chose a Japanese restaurant saying 'Japanese cuisine in Italy sounds interesting'. Andrew, who also chose a Japanese restaurant, was curious 'to find out if the cook is Japanese or Italian'. Finally, Carla chose Italian street food because this 'would be a new experience'.

Students' responses relating: 'I didn't realise'; 'I didn't expect'; 'I wouldn't have thought'; 'I have better insight' reveal a key stage in the move towards breaking down national stereotypes. This choice of words reflect the attitudes identified in Byram's work on intercultural learning with regard to notions of 'curiosity and openness' and a 'readiness to suspend disbelief about other cultures and belief about one's own' (Byram 2008, 163).

While openness and curiosity alone are not enough for developing intercultural understandings, Scarino reminds us that the intercultural process also involves 'interpreting, comparing, connecting, relating and valuing while taking multiple perspectives into account' (Scarino, 2009, 76) For some of the students in our focus group the notion of curiosity is also coupled with the processes of 'interpretation and meaning-making (Scarino, 2009, 74). For example, Sonia said that 'I didn't realise how diverse the country was [referring to Italy], (...) I remember the one I did [referring to her selection in the activity] a Chinese restaurant, there is like Italian style dumplings', reflecting that 'the fusion between two different cultures was so interesting'. Sonia explains that for her this process of exchange is the "Italian culture being used in different cultural contexts'. Likewise, David chose an Italo-Egyptian eatery for the 
activity because he was intrigued by the idea of "eating Italian in Italy but with pluricultural influences'. The word 'fusion' used by Sonia or 'pluricultural influences' highlighted by David reveal the ways students may interpret a context that involves interaction between multiple social realities and ultimately an awareness of cultures and their dynamic relationship.

\section{Student subjectivities}

In addition to attitudes of openness, curiosity and interpretation, student focus group responses also revealed how students' personal dimensions might play a key role in avoiding nationalist trappings while deepening intercultural encounters. In the focus group, students elaborated on the reasons for their dining preferences in the context of the language activity. Their reflections reveal how these choices were informed by their personal experiences. In the activity, Kayla chose a vegan restaurant explaining that 'I am vegan and curious to try this because I prefer healthy food'. Oliver chose a pizzeria because of his Italian heritage and ongoing connection with his grandmother stating that 'my nonna makes pizza'. Focus group responses also underscored these subjectivities. One student selected a traditional Greek restaurant on the basis of his Greek heritage, adding 'It was a typical yeeros shop from Greece and brings back memories'. A similar experience was identified by a student with Sicilian heritage whose choice went beyond Italian food in the general but shaped by regional variations. The student chose Sicilian food because she has family who lives there but she had never had Sicilian cuisine before. She noted that her restaurant choice "was completely different to the stereotypical Italian food, it was pane bread with special things, it wasn't like pizza and pasta'. And yet another student chose a restaurant based on a study abroad experience 
stating 'I looked for this place I had been to with a teacher on an excursion to Italy. I found the restaurant I had been to before that I remember had been really good'. What these examples suggest is that classroom discourse is shaped by a key feature in intercultural education which is a diversity of perspectives as a result of the encounter between students' subjective dimensions and the cultural practices they explore.

This connection to personal experiences has resonance with what Kramsch refers to as subjectivities. For her, language learning is tied to the 'embodied perceptions, memories and emotions of language learners' (Kramsch, 2009). According to Kramsch, this subjectivity is 'produced discursively' (Kramsch, 2014, 215) and is shaped historically and socially 'in interaction with our environment' (215), as well as by 'the meanings we exchange with others' (215). Likewise, Liddicoat and Scarino refer to the relation between language learning and meaning making through 'perceptions, experiences and life worlds of those who participate' in communication $(2013,2)$. By providing opportunities for students in the language activity to connect personal choices with the diverse possibilities inherent in another society, the focus is no longer on the learned culture as an essentialised construct but as a space that finds meaning with the way the student see themselves within the world. With this in mind, according to Mark, the language activity on food opened a space that allowed him to express his personality. He states: 'you want to engage in a language that allows you to express yourself $(\ldots)$ because if you can't it denies you of your personality'. These comments suggest that even at a beginner language level, where language proficiency is still limited, students are keen to explore pathways for the communication of subjectivities that reflect wider socio-cultural contexts. 


\section{Wider social context}

The engagement with diversity and student experiences extends language learning to a wider global social context. Indeed, as Brogan, Kelly and Ó Laoire’s study reveals, intercultural learning 'does not always mean generating 'new' knowledge' about a specific country but can also 'manifest itself as a general interest in other cultures generally and as discovering their own culture' $(2015,178)$. Similarly for the students in the focus group, the language activity did not solely allow them to explore aspects of Italy but to also reflect on broader areas. For instance, Alex said that through the language activity 'it was good to see the diversity, the world moving into a more globalised situation (...) where you have Indian restaurants, sushi places and being exposed to that so that you don't think you're going to be eating pasta for the next six months'. Another student in the focus group expressed that the language activity allowed him to ask himself 'what part of the world do I want to discover in Italy now'? Furthermore, numerous students spoke of the relation between learning a language and the opportunity this unleashes to talk about the world in general. Mark notes that language learning becomes 'more useful when you see it as a tool of communication as opposed to being just about Italy'. He adds that through the language activity on food he 'was able to diversify and not talk just about the culture of that language'. Likewise, David relates that through the language activity 'we use language as a tool to talk about the world'.

The students' reflections in the focus group on the language activity on food align with considerations in intercultural education specifically with regard to student awareness of the relationship between 'language and its broader social, cultural, and political context, as well as how such understanding inhabits within one's conceptualizations of the world' (Anh, 2015, 537). Some of the student responses we 
have seen in this case study contain the premise for agency with regard to how students position themselves within the world around them. In this sense, their worldviews lead a step further to examining and critiquing essentialist ideologies. This process became clear at one stage in the focus group discussion in relation to the students' prescribed language textbook and their perception of the target audience. Two students entered a heated debate about the cultures represented in their textbook. For Matthew, the fact that predominantly European peoples are portrayed is justified because he feels that the target audience using this book is perhaps European. Sonia, however, disagrees by stating that in the textbook 'you should include as many cultures as you can' adding that 'the target audience might not be people from around the world but you should show that there are people from different cultures around the world'. This dynamic suggests Byram's notion of critical engagement which embodies how students 'identify or interpret explicit or implicit values' $(2012,163)$. Sonia's position suggests her awareness of ideologies embedded in the textbook. This awareness came through in the focus group and gave Sonia the ability for enquiry and therefore the potential for social agency through her ability to critique nationalist trappings in language resources.

\section{Concluding remarks}

This study has been informed by the intent to make the language learning space open to the construction of linguistic practices informed by perspectives of diversity. It is based on the premise that awareness of the processes perpetuating conventional discursive practices can set the ground for 'imagining and enacting alternatives to nationalist essentialising' (Cole and Meadows, 2013, 29). This paper extends current research examining how discursive practices may challenges nationalistic conceptions of language learning by including student voices as they engage in and reflect on perspectives of 
diversity. It does so by examining student responses to an Italian language activity centring on eating options in Milan. The data collected suggests that some students reflected skills and attitudes identified in intercultural education such as openness, curiosity and the challenging of assumptions and stereotypical representations. Furthermore, findings revealed the connection between students' discoveries of cultural practices in Italy and their subjectivities. This dimension is relevant in showing how students enact alternatives through interactions with their environment and personal experiences. The data also highlighted how students located the language activity within a broader social context. For some students this social context represented the diversity inherent within Italian society. For others this was translated into a global context and the capacity for language to speak about the world and to position students with the premise for social agency.

Whilst the findings indicate how students involved in the activity enacted alternatives to a nationalist discourse, some of the data in the focus group also revealed that a few students did nevertheless prioritise grammar learning and national representations over engagement with diversity. These variations suggest that the initiatives to challenge nationalist ideologies may not resonate with all students, which has a lot to do with the subjective experiences of each student. As Weninger and Kiss point out in their study on language learning 'how we interpret text and image has a lot to do with our age, gender, (sub)cultural affiliations and experiences' $(2015,18)$.

Challenges however exist in the implementation of a curriculum framed around perspectives of diversity especially at a beginner level where the design of activities takes into consideration students' basic language skills. The design of resources and activities often requires significant investment of time on the part of the teaching staff, however in an era of globalisation, perspectives of diversity are now acknowledged as a significant 
focus of language learning. Developing curricula with these aims while operating within the constraints of demanding workloads in tertiary institutions is a challenging task that deserves consideration. Further studies might explore how such challenges could be resolved.

\section{References}

Abdallah-Pretceille M (2006) Interculturalism as a paradigm for thinking about diversity. Intercultural Education 17 (5): 475-483.

Ahn S-Y (2015) Criticality for global citizenship in Korean English immersion. Language and Intercultural Communication 15 (4): 533-549.

Ashwell MA and Oanh DTH (2009) Developing globally competent citizens: The contrasting cases of the United States and Vietnam. In: Deardorff DK(ed) The SAGE Handbook of Intercultural Competence. Thousand Oaks CA: Sage, pp. 141-157.

Blommaert J and Bulcaen C (2000) Critical discourse analysis. Annual Review of Anthropology 29: 447-466.

Bourdieu P and Passeron J (1977) Reproduction in Education, Society and Culture. Translated by R. Nice. London: Sage.

Brogan K Kelly H and Ó Laoire M (2015) Foreign language learning as intercultural experience: The subjective dimension. In: Witte A and Harden T (eds) Foreign Language Learning as Intercultural Experience: The Subjective Dimension. Oxford: Peter Lang, pp. 165-186.

Byram M and Zarate G (1994) Définitions, Objectifs et Évaluation de la Compétence Socioculturelle. Strasbourg: Report for the Council of Europe.

Byram M (1997) Teaching and Assessing Intercultural Competence. Clevedon: Multilingual Matters.

Byram M (2008) From Foreign Language Education to Education for Intercultural Citizenship: Essays and Reflections. Clevedon: Multilingual Matters.

Byram M (2009a) Multicultural Societies, Pluricultural People and the Project of Intercultural Education. Strasbourg: Council of Europe Publishing. Available at: https://rm.coe.int/multicultural-societies-pluricultural-people-and-the-project-ofinterc/16805a223c (accessed 10 November 2019).

Byram M Barrett M Ipgrave J Jackson R and Méndez-Garcia MC (2009b) Autobiography of Intercultural Encounters: Context, Concepts and Theories. Strasbourg: Council of Europe Publishing. Available at: http://www.coe.int/t/DG4/AUTOBIOGRAPHY/AutobiographyTool_en.asp (accessed 10 November 2019).

Byram M Barrett M Ipgrave J Jackson R and Méndez-Garcia MC (2009c) Autobiography of Intercultural Encounters: Concepts for Discussion. Strasbourg: Council of Europe Publishing. Available at: https://www.coe.int/t/dg4/autobiography/Source/AIE en/AIE context concepts an d theories en.pdf (accessed 10 November 2019).

Byram M (2011) Intercultural citizenship from an international perspective Journal of the NUS Teaching Academy 1(1): 10-20.

Byram M (2012) Language awareness and (critical) cultural awareness - Relationships, comparisons and contrasts. Language Awareness 21(1- 2): 5-13.

Cole D and Meadows B (2013) Avoiding the essentialist trap in intercultural education: Using 
critical discourse analysis to read nationalist ideologies in the language classroom. In Dervin F and Liddicoat AJ (eds) Linguistics for Intercultural Education Amsterdam, Philadelphia, PA: John Benjamins Publishing Company, pp. 29-47.

Dervin F and Liddicoat AJ (eds) (2013) Linguistics for Intercultural Education.

Amsterdam, Philadelphia, PA: John Benjamins Publishing Company.

Dervin F and Liddicoat, AJ (2013) Introduction. In: Dervin F and Liddicoat AJ Linguistics for Intercultural Education. Amsterdam, Philadelphia, PA: John Benjamins Publishing Company, pp.1-25.

Dervin, F and Risager K (eds) (2014) Researching Identity and Interculturality. New York, London: Routledge.

De Vincenti G (2017) Fostering 'knowledge' through representations of eating habits in Italian foreign language textbooks: An intercultural challenge. Forum Italicum 51(3): 761-774.

Fairclough N (1989) Language and Power. London: Longman.

Fairclough N (ed) (1992) Critical Language Awareness. Harlow: Longman.

Fairclough N and Wodak R (1997) Critical discourse analysis: An overview. In: van Dijk TA (ed) Discourse as Social Interaction. London: SAGE, pp. 67-97.

Golden D (2001) 'Now, like real Israelis, let's stand up and sing': Teaching the national language to Russian newcomers in Israel Anthropology \& Education Quarterly 32(1): $52-79$.

Guilherme M (2002) Critical Citizens for an Intercultural World: Foreign Language Education as Cultural Politics. Clevedon: Multilingual Matters.

Holliday A (2011a) Intercultural Communication and Ideology. London: Sage.

Holliday A (2011b) Culture, communication, context and power. In: Jackson J (ed) The Routledge Handbook of Language and Intercultural Communication London: Routledge, pp. 37-51.

Kramsch C (1998) Language and Culture. Oxford, UK: Oxford University Press.

Kramsch C (2006) The multilingual subject. International Journal of Applied Linguistics 16(1): 97-110.

Kramsch C (2012) The Multilingual Subject. What Foreign Language Learners Say about their Experience and Why it Matters. Oxford: Oxford University Press.

Kramsch C (2014) Identity and subjectivity: different timescales different methodologies. In: Dervin F and Risager K (eds) Researching Identity and Interculturality. London, New York: Routledge, pp. 211-230.

Liddicoat A and Scarino A (2013) Intercultural Language Teaching and Learning. Oxford: Wiley-Blackwell.

Meadows B (2009) Nationalism and Language Learning at the US/Mexico Border: An Ethnographically-Sensitive Critical Discourse Analysis of the Reproduction of Nation, Power, and Privilege in an English Language Classroom. (Unpublished doctoral dissertation). University of Arizona, Tucson, AZ.

Meadows B (2010) 'Like my tutor and stuff, people I would talk to': Laying claim to imagined national communities in learner discourse. Critical Inquiry in Language Studies, 7(2-3), 88-111.

Morgan A-M Kohler M and Harbon L (2011) Developing intercultural language learning textbooks: Methodological trends, engaging with the intercultural construct, and personal reflections on the process. IARTEM e-Journal. 4(1): 20-51.

Paavola H and Dervin F (2015) The alphabet gone wrong? Diversities in three Finnish ABC books. In: Hahl K Niemi P-M Johnson Longfor R and Dervin F Diversities and Interculturality in Textbooks: Finland as an Example. Newcastle upon Tyne: Cambridge Scholars Publishing, pp. 17-36.

Paltridge B (2006) Discourse Analysis: An Introduction. London: Continuum.

Risager K (2007) Language and Culture Pedagogy: From a National to a Transnational Paradigm. Clevedon: Multilingual Matters.

Risager K and Dervin F (2014) Introduction. In: Dervin F and Risager K Researching Identity and Interculturality. London, New York: Routledge, pp. 1-25. 
Malancharuvil-Berkes E Mosley M Hui D and O'Garro JG (2005) Critical discourse analysis in education: A review of the literature. Review of Educational Research. 75 (3): 365-416.

Starkey H (2009) Language education, identities and citizenship: Developing cosmopolitan perspectives. Language and Intercultural Communication 7(1): 56-71.

van Dijk TA (1998) Ideology. London: SAGE.

van Dijk TA (2001) Critical discourse analysis. In: Schiffrin D. Tannen D and Hamilton H The Handbook of Discourse Analysis. Malden, MA: Blackwell, pp. 352-371.

Weninger C and Kiss T (2013) Culture in English as a foreign language (EFL) textbooks: A semiotic approach. TESOL Quarterly 47 (4): 694-716.

Weninger $\mathrm{C}$ and Kiss T (2015) Analyzing culture in foreign language textbooks:

Methodological and conceptual issues. In: Curdt-Christiansen $\mathrm{X}$ and Weninger $\mathrm{C}$ Language, Ideology and Education: The Politics of Textbooks in Language Education. Abingdon: Routledge, pp. 50-66. 